B I O S C I E N C E

J O U R N A L

\title{
INCREASING POPULATION DENSITY REDUCES SOYBEAN YIELD COMPONENTS AND PRODUCTIVITY
}

Marcelo de Almeida SILVA ${ }^{1}$ (D), Ana Carolina de Santana SOARES ${ }^{2}$ (D), Melina Rodrigues Alves CARNIETTO2 ${ }^{2}$, Alexandrius de Moraes BARBOSA ${ }^{3}$

\footnotetext{
${ }^{1}$ Department of Crop Production, Laboratory of Ecophysiology Applied to Agriculture, School of Agricultural Sciences, São Paulo State University, Botucatu, São Paulo Brazil.

2 Postgraduate Program in Agriculture, Laboratory of Ecophysiology Applied to Agriculture, School of Agricultural Sciences, São Paulo State University, Botucatu, São Paulo Brazil.

${ }^{3}$ Department of Crop Production, University of Western São Paulo, Presidente Prudente, São Paulo, Brazil.
}

Corresponding author:

Marcelo de Almeida Silva

Email: marcelo.a.silva@unesp.br

How to cite: SILVA, M.A., et al. Increasing population density reduces soybean yield components and productivity. Bioscience Journal. 2021, 37, e37042. https://doi.org/10.14393/BJ-v37n0a2021-53612

\begin{abstract}
Studies addressing the interaction of different spatial arrangement in soybean are needed in order to achieve management that leads to higher grain yield associated with rational seed use. The objective of this work was to evaluate the yield components and productivity of an undetermined growth type soybean as a function of different row spacing and plant densities. The treatments consisted of three row spaces $(0.25$, 0.35 and $0.45 \mathrm{~m})$ and three plant population densities $\left(30,40\right.$ and 50 plants $\left./ \mathrm{m}^{2}\right)$. There was no interaction of row spaces and plant population on soybean yield. Regarding the overall spacing average, the grain yield of the population of $30 / \mathrm{m}^{2}$ plants was higher than the productivity of the populations of 40 and $50 / \mathrm{m}^{2}$ plants. The largest populations reduce plant sizes due to greater competition between plants. In addition, smaller populations promote higher individual plant yields due to the increase components of the production. This characteristic is defined as the ability of the plant to change its morphology and yield components in order to adapt to the conditions imposed by the spatial arrangement.
\end{abstract}

Keywords: Glycine $\max ($ L.) Merrill. Plant Population. Spatial Arrangement. Yield.

\section{Introduction}

In recent decades, the soybean crop production system has undergone several changes, such as soil tillage system, fertility management, phyto-sanitary management, new production environments, use of transgenic genotypes. These factors promoted changes in the spatial arrangement of plants, and this arrangement is defined by sowing density (plants per hectare), row spacing and uniform distribution of plants within these rows.

Several studies addressing population density in soybean have been completed. Although the objectives of these studies were mainly to evaluate yield as a function of reduction in population, row spacing reduction and cross-sowing of determined growth type cultures. In most of the results little effect of population arrangement on grain yield was observed (Tourino et al. 2002; Rambo et al. 2003; Heiffig et al. 2006; Procópio et al. 2013; Balbinot Junior et al. 2015a; Balbinot Junior et al. 2015b; Petter et al. 2016; Souza et al. 2016; Andrade et al. 2016).

Generally, populations ranging from 160,000 to 360,000 soybean plants per hectare have little effect on grain yield as long as the plants are evenly distributed in the area (Luca and Hungria 2014; Balbinot Junior 
et al. 2015b). This occurs due soybeans having high phenotypic plasticity, modulating their growth and yield components against changes in plant arrangement (Procópio et al. 2013).

However, in recent years, the use of undetermined growth type soybean and new row spacing patterns associated with the high cost of genetically modified seeds in Brazil has stimulated further studies addressing the evaluation of plants arrangements aimed at increasing yields of grains along with the reduction in plant density (Ferreira et al. 2018).

Most studies on soybean cultivation evaluated plant distribution in isolation, that is, either considering only plant density or only row spacing. In this sense, studies addressing the interaction of different types of spatial arrangement of plants in soybean crop of undetermined growth type are necessary in order to obtain management that leads to higher grain yield associated with rational use of seeds.

The objective of this work was to evaluate the yield components and grain yield of soybean of undetermined growth type as a function of different row spacing and plant densities.

\section{Material and Methods}

The experiment was carried out at the Faculdade de Ciências Agronômicas (FCA) of Universidade Estadual Paulista "Júlio de Mesquita Filho" (UNESP), campus Botucatu-SP, during the 2016-2017 harvest season. The soil of the experimental area was classified as Dystroferric Red Nitosol (Santos et al. 2018). It had the following chemical attributes, in the 0 to $0.20 \mathrm{~m}$ layer: $30,0 \mathrm{~g} / \mathrm{dm}^{3}$ of organic matter; 5,1 of $\mathrm{pH}$ in $\mathrm{CaCl}_{2} ; 22.7 \mathrm{mg} / \mathrm{dm}^{3}$ of $\mathrm{P} ; 5,1 \mathrm{mmolc} / \mathrm{dm}^{3}$ of $\mathrm{K} ; 36 \mathrm{mmolc} / \mathrm{dm}^{3}$ of $\mathrm{Ca} ; 12 \mathrm{mmolc} / \mathrm{dm}^{3}$ of $\mathrm{Mg}$; e $55 \%$ base saturation of CTC.

The experimental design contained random blocks with plots split in four replications. The main plot consisted of three row spacings $(0.25,0.35$ and $0.45 \mathrm{~m})$. Subdivided plot consisted of three plant population densities (30, 40 e 50 plants $/ \mathrm{m}^{2}$ ). The experimental plot consisted of five rows of sowing by ten meters in length, where the spacing between rows was according to each treatment.

BMX Potência RR, with characteristics of undetermined growth type, maturity group 6.7, and developmental cycle ranging from 116 to 125 days was used. Sowing occurred on November $21^{\text {st }}, 2016$ in no-tillage system with application of $300 \mathrm{~kg} / \mathrm{ha}$ of NPK formulated fertilizer 02-20-20 in the furrow. The seeds were treated with fungicides thiabenazole (15 g a. i./100 kg of seed) + captana (90 g a. i./100 kg of seeds), and inoculated at the time of sowing with Bradyhizobium japonicum bacteria, applied to the seeds as 100 $\mathrm{mL}$ per $60 \mathrm{~kg}$ of seed. The relevant weather data collected during the experiment can be found on Table 1. The sowing was done to reach 80 plants $/ \mathrm{m}^{2}$ and after germination, the plants were thinned according to the population of each treatment at growth stage V4, according to the scale developed by Fehr and Caviness (1977).

At the stages R2, R3, R4 and R5 were evaluated the plant's height, number of leaves per plant, leaf area (AF), leaf area index (LAl) and dry matter mass. For these analyzes were used ten plants, located in the first 5 meters reserved for destructive collection in the useful area of each plot. The first assessment (R2) was performed on the first meter, the second (R3) on the second meter and so on.

The average plant height was measured with measuring tape, from the soil surface to the apical end of the main stem. Next, the plants were collected and packed in paper bags and taken to the laboratory. In the laboratory the leaves of each plant were detached, cleaned, and counted. Leaf area was measured using a leaf area meter (LI-COR, LI-3100C, Lincoln, NE, USA). The LAI was obtained through the relationship between the leaf area and the land area occupied by the plant in the different population arrangements. 
Table 1. Climatic data recorded during the experiment. Botucatu, SP, Brazil, 2016/17 harvest season.

\begin{tabular}{lccccc}
\hline $\begin{array}{l}\text { Phenological } \\
\text { phases* }\end{array}$ & Period & $\begin{array}{c}\mathrm{N}^{\circ} \text { of } \\
\text { days }\end{array}$ & $\begin{array}{c}\text { Total } \\
\text { precipitation } \\
(\mathrm{mm})\end{array}$ & $\begin{array}{c}\text { Total solar radiation } \\
\left(\mathrm{cal} / \mathrm{cm}^{2} . \mathrm{d}\right)\end{array}$ & $\begin{array}{c}\text { Average } \\
\text { temperature } \\
\left({ }^{\circ} \mathrm{C}\right)\end{array}$ \\
\hline S - VE & $\begin{array}{c}21 / 11 / 2016 \text { to } \\
26 / 11 / 2016\end{array}$ & 5 & 30.8 & $2,457.9$ & 27.2 \\
VE - R1 & $\begin{array}{c}26 / 11 / 2016 \text { to } \\
01 / 01 / 2017\end{array}$ & 36 & 473.9 & $11,738.7$ & 27.6 \\
R1 - R5 & $\begin{array}{c}01 / 01 / 2017 \text { to } \\
04 / 02 / 2017\end{array}$ & 34 & 401.9 & $10,227.2$ & 25.7 \\
R5 - R8 & $\begin{array}{c}04 / 02 / 2017 \text { to } \\
24 / 03 / 2017\end{array}$ & 48 & 415.8 & $13,968.9$ & 25.9 \\
\hline Total & - & 123 & $1,322.4$ & $38,392.7$ & - \\
Average & - & - & - & - & 26.6 \\
\hline
\end{tabular}

*S - sowing; VE - emergency; $R_{1}$ - early flowering; $R_{5}$ - early of granation; $R_{8}$ - field maturity.

To obtain the dry matter mass, leaves and stems dried at $65^{\circ} \mathrm{C}$ to constant mass. At 123 days after sowing (DAS) the pod, grain numbers per plant, and the grain yield were determined. Pod and grain numbers per plant were determined in a sample of 12 plants. The number of pods was obtained by direct counting in each plant. These pods were collected and threshed manually and the total number of grains per plant determined by direct counting.

Grain yield was obtained in four linear meters of each plot, making a total of 12 linear meters of the useful area of each experimental plot. With the aid of mechanical plot harvester, and subsequent weighing of the grains and standardization of moisture degree to $13 \%$ on wet basis, determined by the oven method at $105^{\circ} \mathrm{C} \pm 3$ for 24 hours (Brasil 2009).

Data was subjected to analysis of variance to compare the effect of treatments on the parameters analyzed. When the value of the $F$ test indicated a significant effect, the Tukey test $(p<0.05)$ was used to compare the differences between treatments.

\section{Results and Discussion}

In general, there was a greater effect in increasing population density (30 to 50 plants $/ \mathrm{m}^{2}$ ), than spacing $(0.25,0.35$ and $0.45 \mathrm{~m})$, with little interaction between treatments. Plant height or population was not influenced by spacing. The average plant height at R5 stage was $0.9 \mathrm{~m}$ (Table 2). 
Table 2. Biometric parameters of soybean as a function of sowing spacing $(0.25,0.35$ and $0.45 \mathrm{~m})$ and three population densities $\left(30,40\right.$ and 50 plants $\left./ \mathrm{m}^{2}\right)$.

\begin{tabular}{|c|c|c|c|c|}
\hline \multirow{3}{*}{ Spacing $(\mathrm{m})$} & \multicolumn{3}{|c|}{ Population (plants $/ \mathrm{m}^{2}$ ) } & \multirow[b]{3}{*}{ Average } \\
\hline & 30 & 40 & 50 & \\
\hline & & \multicolumn{2}{|c|}{ Plant heigh (m) } & \\
\hline 0.25 & $0.87^{\mathrm{aA}}$ & $0.91^{\mathrm{aA}}$ & $0.92^{\mathrm{aA}}$ & $0.90^{\mathrm{a}}$ \\
\hline 0.35 & $0.92^{\mathrm{aA}}$ & $0.94^{\mathrm{aA}}$ & $0.95^{\mathrm{aA}}$ & $0.94^{a}$ \\
\hline 0.45 & $0.85^{\mathrm{aA}}$ & $0.90^{\mathrm{aA}}$ & $0.91^{\mathrm{aA}}$ & $0.89^{a}$ \\
\hline Average & $0.88^{\mathrm{A}}$ & $0.92^{\mathrm{A}}$ & $0.93^{\mathrm{A}}$ & \\
\hline \multicolumn{5}{|c|}{ Dry mass per plant (DMP, g) } \\
\hline 0.25 & $28.98^{\mathrm{aA}}$ & $24.46^{\mathrm{aA}}$ & $22.64^{\mathrm{aA}}$ & $25.36^{a}$ \\
\hline 0.35 & $28.58^{\mathrm{aA}}$ & $28.46^{\mathrm{aA}}$ & $25.95^{\mathrm{aA}}$ & $27.66^{a}$ \\
\hline 0.45 & $26.32^{\mathrm{aA}}$ & $25.16^{\mathrm{aA}}$ & $21.95^{\mathrm{aA}}$ & $24.47^{a}$ \\
\hline Average & $27.96^{\mathrm{A}}$ & $26.02^{A B}$ & $23.51^{\mathrm{B}}$ & \\
\hline \multicolumn{5}{|c|}{ Dry mass yield (kg/ha) } \\
\hline 0.25 & $7.08^{\mathrm{aA}}$ & $8.15^{\mathrm{aA}}$ & $9.53^{\mathrm{aA}}$ & $8.27^{a}$ \\
\hline 0.35 & $7.21^{\mathrm{aB}}$ & $9.48^{\mathrm{aAB}}$ & $10.93^{\mathrm{aA}}$ & $9.21^{\mathrm{a}}$ \\
\hline 0.45 & $6.58^{\mathrm{aB}}$ & $8.58^{\mathrm{aAB}}$ & $9.29^{\mathrm{aA}}$ & $8.15^{\mathrm{a}}$ \\
\hline Average & $6.96^{\mathrm{B}}$ & $8.74^{\mathrm{A}}$ & $9.92^{\mathrm{A}}$ & \\
\hline
\end{tabular}

Means followed by the same lower case letters in a column and capital letters on the lines, within the same parameter, do not differ significantly by the Tukey test $(p<0.05)$.

In relation to dry mass per plant (DMP), there was effect only on the general average of plant populations, the highest MSPA per plant was observed in the population of 30 plants $/ \mathrm{m}^{2}$, while the lowest in the population of 50 plants $/ \mathrm{m}^{2}$. The DMP per hectare in the 0.35 and $0.45 \mathrm{~m}$ spacing, as well as in the general average, was higher in the largest plant population.

The leaf area of the soybean plant throughout the cycle varied according to the plant population. The population of 30 plants $/ \mathrm{m}^{2}$ promoted the largest leaf area, and the leaf area was reduced as the plant population increased (Figure 1A). The spacing did not influence the leaf area of the plants. However, in the R6 stage at the $0.25 \mathrm{~m}$ spacing, the largest leaf area was obtained by the smaller plant population. Also, in the general average, the leaf area was larger in the population 30 plants $/ \mathrm{m}^{2}\left(1,332.39 / \mathrm{cm}^{2}\right)$ and lower in the population of 50 plants $/ \mathrm{m}^{2}\left(1,020.65 / \mathrm{m}^{2}\right)$ (Table 3$)$.

The leaf area index (LAI) was higher in the population of $50 / \mathrm{m}^{2}$ plants throughout the crop cycle, as well as the lowest LAI was observed in the population of 30 plants $/ \mathrm{m}^{2}$ (Figure 1B). In the three populations studied, the highest LAl occurred between 65 and 66 DAS, which coincided with the R3 stage. In this period, the LAl peak was $6.2 ; 7.0$ and 8.0 in the 30,40 and 50 plants $/ \mathrm{m}^{2}$ populations, respectively. At stage $R 6$ the highest LAI was obtained by the population of $50 / \mathrm{m}^{2}(5.1)$ and the lowest by the population of $30 / \mathrm{m}^{2}$ plants (4.0) (Table 3).

The total number of pods and grains was influenced only by population density (Figure 2). The highest number of grains and pods was observed in the treatment with lower population density $\left(30 / \mathrm{m}^{2}\right.$ plants). As the population density increased, the pods and grains numbers decreased. The number of grains per plant was 90,81 and 67 in the populations of 30,40 and 50 plants $/ \mathrm{m}^{2}$, respectively. 



Figure 1. A - leaf area; $B$ - leaf area index (LAI) of soybean plants in four phenological stages R2 (48 DAP); R3 (55 DAP); R5 (75 DAP) and R6 (82 DAP) under three population densities $\left(30,40\right.$ and 50 plants $\left./ \mathrm{m}^{2}\right)$.

Table 3. Leaf area and leaf area index (LAI) of soybean as a function of sowing spacing $(0.25,0.35$ and 0.45 $\mathrm{m})$ and three population densities (30, 40 and 50 plants $\left./ \mathrm{m}^{2}\right)$.

\begin{tabular}{|c|c|c|c|c|}
\hline \multirow{2}{*}{ Spacing (m) } & \multicolumn{3}{|c|}{ Population (plants $/ \mathrm{m}^{2}$ ) } & \multirow{2}{*}{ Average } \\
\hline & 30 & 40 & 50 & \\
\hline \multicolumn{5}{|c|}{ Leaf area $\left(\mathrm{cm}^{2}\right)$} \\
\hline 0.25 & $1,466.98^{\mathrm{aA}}$ & $1,198.25^{\mathrm{aAB}}$ & $992.16^{\mathrm{aB}}$ & $1,219.13^{a}$ \\
\hline 0.35 & $1,289.51^{\mathrm{aA}}$ & $1,299.98^{\mathrm{aA}}$ & $1121.97^{\mathrm{aA}}$ & $1,237.15^{a}$ \\
\hline 0.45 & $1,240.70^{\mathrm{aA}}$ & $1,157.19^{\mathrm{aA}}$ & $947.82^{\mathrm{aA}}$ & $1,115.23^{a}$ \\
\hline Average & $1,332.39^{A}$ & $1,218.47^{\mathrm{AB}}$ & $1,020.65^{B}$ & \\
\hline \multicolumn{5}{|c|}{ Leaf area index (LAI) } \\
\hline 0.25 & $4.40^{\mathrm{aA}}$ & $4.79^{\mathrm{aA}}$ & $4.96^{\mathrm{aA}}$ & $4.72^{a}$ \\
\hline 0.35 & $3.87^{\mathrm{aB}}$ & $5.20^{\mathrm{aAB}}$ & $5.61^{\mathrm{aA}}$ & $4.89^{a}$ \\
\hline 0.45 & $3.72^{\mathrm{aA}}$ & $4.63^{\mathrm{aA}}$ & $4.74^{\mathrm{aA}}$ & $4.36^{a}$ \\
\hline Average & $4.00^{\mathrm{B}}$ & $4.87^{A B}$ & $5.10^{\mathrm{A}}$ & \\
\hline
\end{tabular}

Means followed by the same lower case letters in a column and capital letters on the lines, within the same parameter, do not differ significantly by the Tukey test $(p<0.05)$. 


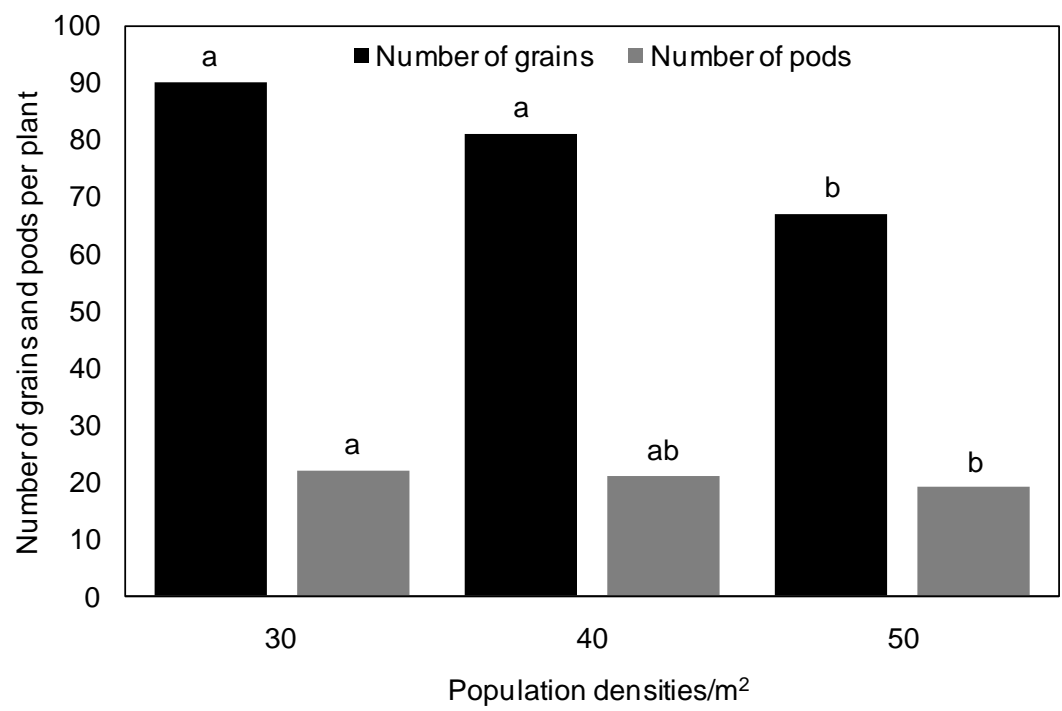

Figure 2. Total number of grains and pods per plant under three population densities $(30,40$ and 50 plants $/ \mathrm{m}^{2}$ ). Means followed by the same lowercase letters within the same color bar do not differ significantly by the Tukey test $(p<0.05)$.

There was no interaction of spacing, and plant population on soybean yield (Table 4). Regarding the average spacing, the grain yield of the population of $30 / \mathrm{m}^{2}$ plants $(2,838.25 \mathrm{~kg} / \mathrm{ha})$ was higher than the population productivity of 40 and $50 / \mathrm{m}^{2}$ plants $(2,541.76 \mathrm{~kg} / \mathrm{ha})$. In the population of $30 / \mathrm{m}^{2}$ plants the grain yield was $11.6 \%$ higher than the average productivity of the populations of 40 and $50 / \mathrm{m}^{2}$ plants. Regarding the weight of 100 grains, there was no difference and interaction between treatments (data not shown), in which the average weight of 100 grains of all treatments was $18.06 \mathrm{~g}$.

In this study two different ways to perform the spatial distribution of plants in soybean were evaluated. First, in a culture of undetermined growth type, one by reducing the row spacing, secondly, through the population increase of plants, as well as the interaction of these managements. In general, there was no effect of reducing row spacing from 0.45 to $0.25 \mathrm{~m}$ on grain yield and yield components.

In recent years, several studies have been conducted to address the spatial arrangement of plants in soybean through reduced row spacing (Tourino et al. 2002; Rambo et al. 2003; Heiffig et al. 2006), increasing density (Petter et al. 2016; Souza et al. 2016) and cross-sowing (Procópio et al. 2013; Balbinot Junior et al. 2015a; Andrade et al. 2016). In most of these studies it was observed that soybean yield is little influenced or negatively influenced with increasing plant density (Tourino et al. 2002; Heiffig et al. 2006; Petter et al. 2016; Souza et al. 2016; Andrade et al. 2016).

In the present study, the yield components and grain yield were not influenced by the reduction of spacing from 0.25 to $0.45 \mathrm{~m}$, where the average yield was $2.640 \mathrm{~kg} / \mathrm{ha}$ (Table 4). Tourino et al. (2012) did not identify differences in soybean yield by evaluating the 0.40 and $0.60 \mathrm{~m}$ spacing at five population densities (10 to 22 plants $/ \mathrm{m}^{2}$ ). Additionally, Rambo et al. (2003) evaluated soybean yield in two row spacings $(0.20$ and $0.40 \mathrm{~m}$ ) in three plant populations $\left(20,30\right.$ and 40 plants $\left./ \mathrm{m}^{2}\right)$, and reported increased yield only in the interaction 20 plants $/ \mathrm{m}^{2}$ with $0.20 \mathrm{~m}$ between spacing. While Heiffig et al. (2006) evaluated soybean yield in six rows spacing $(0.20$ to $0.70 \mathrm{~m})$ and six plant's populations $\left(7.0\right.$ to 35.0 plants $\left./ \mathrm{m}^{2}\right)$ and found no difference in any combination of treatments.

Table 4. Soybean grain yield as a function of row spacing and plant population.

\begin{tabular}{ccccc}
\hline \multirow{2}{*}{ Spacing $(\mathrm{cm})$} & 30 & 40 & 50 & \multirow{2}{*}{ Average } \\
\cline { 2 - 4 } & $2,764.66^{\mathrm{a}}$ & $2,512.49^{\mathrm{a}}$ & $2,428.14^{\mathrm{a}}$ & $2,568.43^{\mathrm{a}}$ \\
0.25 & $2,848.92^{\mathrm{a}}$ & $2,470.39^{\mathrm{a}}$ & $2,556.65^{\mathrm{a}}$ & $2,630.32^{\mathrm{a}}$ \\
0.35 & $2,898.18^{\mathrm{a}}$ & $2,711.25^{\mathrm{a}}$ & $2,571.66^{\mathrm{a}}$ & $2,722.02^{\mathrm{a}}$ \\
0.45 & $2,838.25^{\mathrm{A}}$ & $2,564.71^{\mathrm{B}}$ & $2,518.81^{\mathrm{B}}$ & \\
\hline Average & 2,5 . & \\
\hline
\end{tabular}

Means followed by the same lower case letters in a column and capital letters on the lines do not differ significantly by the Tukey test $(p<0.05)$. 
In studies conducted by Gan et al. (2002) and Procópio et al. (2013) also did not observe an increase in soybean yield due to different densities and population arrangements. The authors reported that soybean crop has a high capacity to modulate its growth as a function of population density, mainly growing cultures of undetermined type, making grain yield less sensitive to plant management.

Grain yield is not influenced by the fact that soybean has high phenotypic plasticity, therefore, yield is little influenced by plant density (Balbinot Junior et al. 2015b). In this work, the reduction in grain yield was close to $11 \%$ due to the increase in population density, where this reduction was associated with the reduction of the main components of plant production (dry mass, leaf area, number of pods, and grains).

With increasing population density, there was a reduction of 13 and $25 \%$ in the number of pods and grains per plant, respectively. Other studies have also observed a reduction in the number of pods per plant as a function of population increase. Mauad et al. (2010) observed a reduction close to $36 \%$, while Souza et al. (2016) reported a reduction in the number of pods per plant due to a population increase of 22 to $37 \%$. Increasing plant population density promotes water, light and nutrient competition, reducing the individual productive potential of the plant, which in turn causes a reduction in leaf area and production components, especially in the number of branches, pods and grains per plant.

Larger plant populations promoted higher leaf area index and dry mass yield ( $\mathrm{kg} / \mathrm{ha})$. This fact is related to the larger number of plants obtained in the highest population densities, in which a compensatory effect occurs, where the low individual development of the plant is compensated by the increase of the number of plants per unit of area.

The maximum LAl occurred at approximately 66 DAS, which in this case corresponded between stages R3 and R4. In work conducted by Heiffig et al. (2006) the largest LAI in five soybean populations occurred between stages R4 and R5. The reduction in leaf area index in this period is related to the beginning of leaf senescence of the lower third of the plant, in which, after this period, the plant prioritizes its development for grain filling.

In a recent study by Balbinot Junior et al. (2018) with five population densities, it was observed that the maximum LAI of two genotypes was obtained from the R.3 stage. The authors reported that LAl smaller than 6.5 may limit productivity due to lower light interception and biomass conversion. LAl values higher than 7.0 can cause reduction in productivity due to increased energy expenditure of plants in respiration and photorespiration.

However, the compensatory effect of the larger amount of plants does not occur for grain yield, because as the plant population increases the individual plant yield is greatly reduced. This is related to the fact that at higher densities there is greater competition for light, and less availability of photo assimilates, causing the plant to shrink the number of branches and produce fewer nodes (Hanway and Thompson 1967). At lower sowing densities, the higher yield of pods is explained by the increase in the number of branches, which determines the higher knot potential and, thus, the greater number of pods per plant (Mauad et al. 2010).

\section{Conclusions}

Our studies have shown that soybean culture of undetermined growth type has high plasticity in plant population management, where larger populations reduce plant size due to greater competition between plants, while smaller populations promote higher individual yield of plants due to increased production components. This characteristic is defined as the capacity of the plant to alter its morphology, and yield components to adapt them to the conditions imposed by the spatial arrangement of the individuals.

Authors' Contributions: SILVA, M.A.: conception and design, analysis and interpretation of data, and drafting the article; SOARES, A.C.S.: acquisition, analysis and interpretation of data, drafting the article; CARNIETTO, M.R.A.: drafting the article; BARBOSA, A.M.: analysis and interpretation of data, drafting the article. All authors have read and approved the final version of the manuscript.

Conflicts of Interest: The authors declare no conflicts of interest.

Ethics Approval: Not applicable.

Acknowledgments: The authors would like to thank the funding for the realization of this study provided by the Brazilian agency CNPq (Conselho Nacional de Desenvolvimento Científico e Tecnológico - Brasil), Finance Code 305952/2018-8. 


\section{References}

ANDRADE, F.R., et al. Características agronômicas e produtivas da soja cultivada em plantio convencional e cruzado. Revista de Agricultura. 2016, 91(1), 81-91. https://doi.org/10.37856/bja.v91i1.181

BALBINOT JUNIOR, A.A., et al. Semeadura cruzada em cultivares de soja com tipo de crescimento determinado. Semina: Ciências Agrárias. 2015a, 36(3), 1215-1226. http://dx.doi.org/10.5433/1679-0359.2015v36n3p1215

BALBINOT JUNIOR, A.A., et al. Espaçamento reduzido e plantio cruzado associados a diferentes densidades de plantas de soja. Semina: Ciências Agrárias. 2015b, 36(5), 2977-2986. http://dx.doi.org/10.5433/1679-0359.2015v36n5p2977

BALBINOT JUNIOR, A.A., et al. Índice de área foliar da soja em função da redução da densidade de semeadura. Boletim de Pesquisa e Desenvolvimento 17. Londrina: Embrapa Soja, 2018.

BRASIL. Ministério da Agricultura, Pecuária e Abastecimento. Regras para Análises de Sementes. Ministério da Agricultura, Pecuária e Abastecimento. Secretaria de Defesa Agropecuária. Brasília: MAPA/ACS, 395p, 2009. Available from: https://www.gov.br/agricultura/ptbr/assuntos/insumos-agropecuarios/arquivos-publicacoes-insumos/2946 regras analise sementes.pdf

FEHR, W.R. and CAVINESS, C.E. Stages of soybean development. Cooperative Extension Service, Agriculture and Home Economics Experiment Station, 1977.

FERREIRA, A.S., ZUCARELI, C., WERNER, F. and BALBINOT JUNIOR, A.A. Plant spatial arrangement affects grain production from branches and stem of soybean cultivars. Bragantia. 2018, 77(4), 567-576. https://doi.org/10.1590/1678-4499.2017285

GAN, Y., STULEN, I., VAN KEULEN, H. and KUIPER, P.J. Physiological response of soybean to plant density. Field Crops Research. 2002, 74(2-3), 231-241. https://doi.org/10.1016/S0378-4290(01)00212-X

HANWAY, J.J. and THOMPSON, H.E. How a soybean plant develops. Special Report 53. lowa State University of Science and Technology Cooperative Extension Service, 1967.

HEIFFIG, L.S., et al. Fechamento e índice de área foliar da cultura da soja em diferentes arranjos espaciais. Bragantia. 2006, 65(2), 285-295. https://doi.org/10.1590/S0006-87052006000200010

LUCA, M.J. and HUNGRIA, M. Plant densities and modulation of symbiotic nitrogen fixation in soybean. Scientia Agricola. 2014, 71(3), 181-187. https://doi.org/10.1590/S0103-90162014000300002

MAUAD, M., et al. Influência da densidade de semeadura sobre características agronômicas na cultura da soja. Revista Agrarian. 2010, 3(9), 175-181.

PETTER, F.A., et al. Elevada densidade de semeadura aumenta a produtividade da soja? Respostas da radiação fotossinteticamente ativa. Bragantia. 2016, 75(2), 173-183. https://doi.org/10.1590/1678-4499.447

PROCÓPIO, S.O., et al. Plantio cruzado na cultura da soja utilizando uma cultivar de hábito de crescimento indeterminado. Revista de Ciências Agrárias. 2013, 56(4), 319-325. http://dx.doi.org/10.4322/rca.2013.048

RAMBO, L., et al. Rendimento de grãos da soja em função do arranjo de plantas. Ciência Rural. 2003, 33(3), 405-411. https://doi.org/10.1590/S0103-84782003000300003

SANTOS, H.G., et al. Sistema brasileiro de classificação de solos. Brasília: EMBRAPA, 2018.

SOUZA, R., TEIXEIRA, I., REIS, E. and SILVA, A. Soybean morphophysiology and yield response to seeding systems and plant populations. Chilean Journal of Agricultural Research. 2016, 76(1), 3-8. http://dx.doi.org/10.4067/S0718-58392016000100001

TOURINO, M.C., REZENDE, P.M. and SALVADOR, N. Espaçamento, densidade e uniformidade de semeadura na produtividade e características agronômicas da soja. Pesquisa Agropecuária Brasileira. 2002, 37(8), 1071-1077. https://doi.org/10.1590/S0100-204X2002000800004

Received: 7 April 2020 | Accepted: 11 September 2020 | Published: 20 August 2021

This is an Open Access article distributed under the terms of the Creative Commons Attribution License, which permits unrestricted use, distribution, and reproduction in any medium, provided the original work is properly cited. 